Article

\title{
Strategic Alliance for Resilience in Supply Chain: A Bibliometric Analysis
}

\author{
Maryam Philsoophian ${ }^{1}$, Peyman Akhavan ${ }^{1,2, *}$ and Morteza Abbasi ${ }^{1}$ \\ 1 Industrial Engineering Department, Malek Ashtar University of Technology, Tehran 1774-15875, Iran; \\ philsoophian@mut.ac.ir (M.P.); mabbasi@mut.ac.ir (M.A.) \\ 2 Industrial Engineering Department, Qom University of Technology, Qom 3718-146645, Iran \\ * Correspondence: akhavan@mut.ac.ir
}

Citation: Philsoophian, M.; Akhavan, P.; Abbasi, M. Strategic Alliance for Resilience in Supply Chain: A Bibliometric Analysis. Sustainability 2021, 13, 12715. https://doi.org/ $10.3390 /$ su132212715

Academic Editors:

Yoshiki Shimomura and

Shigeru Hosono

Received: 2 November 2021

Accepted: 13 November 2021

Published: 17 November 2021

Publisher's Note: MDPI stays neutral with regard to jurisdictional claims in published maps and institutional affiliations.

Copyright: (c) 2021 by the authors. Licensee MDPI, Basel, Switzerland. This article is an open access article distributed under the terms and conditions of the Creative Commons Attribution (CC BY) license (https:/ / creativecommons.org/licenses/by/ $4.0 /)$.
Abstract: Resilience is a particularly important quality for supply chains in this turbulent environment. Resilience in the supply chain is the ability to retain, resume, and recover operations after an intense destructive incident. One of the strategic solutions for managing supply chain disruptions is to establish collaboration and strategic alliances in order to achieve competitive advantage. Therefore, given the increasing publication of articles in areas of strategic alliances and supply chain resilience, it is a good opportunity to review these articles, identify gaps in the current literature, demonstrate links between the two areas, and provide suggestions for future research. For these purposes, a bibliometric analysis has been performed on literature available on the Web of Science database. The distribution of articles based on year and country, influential journals, research areas, authors, affiliations, keywords, citations, and reference co-citation analysis are discussed. Results indicate that studies about strategic alliances, meant to increase resilience, are growing in areas such as "Management", “Operations research", "Management science”, and "Business". Furthermore, the sources could be categorized into five clusters; namely "From knowledge concept to value creation", "Internal and external relationships", "Logistics and supply chain performance", "Intellectual capital and strategic management", and "Critical success factors and alliances". This article can be useful for both practitioners and academics who explore the topic of strategic alliances and resilience in the supply chain, and also offers managers the opportunity to overcome supply chain disruptions and negative consequences of risks by becoming familiar with the key concepts of resilience. The persistence of businesses and supply chains is guaranteed through communicating with partners and even competitors in the light of alliance according to the findings of this research. Managers can pay attention to the integration of the supply chain to improve resilience and increase collaboration between suppliers and customers. Given the research results, strategic alliances can be noted in expanding organizational entrepreneurship and shaping strategic collaboration networks in light of strategic alliances.

Keywords: strategic alliance; supply chain resilience; resilient supply chain; bibliometric analysis

\section{Introduction}

In recent years, the number of studies in the field of supply chain resilience has increased. Both managers and scholars are more concerned about the impact of widespread disruptions in the supply chain and pay attention to controlling the factors that affect the supply chain [1]. These disruptions are irreparable and usually occur due to natural disasters, fires, terrorist activities, or environmental changes [2]. Therefore, it is necessary to decrease the impact of supply chain disruptions through resilient actions [3]. Indeed, resilience in a supply chain can be defined as a company's ability to resist disruption, recover to the original state, and even move toward a more favorable situation after experiencing disruption. Resilience reveals the extent to which a supply chain is able to withstand disruptions while maintaining function [4]. 
Resilience seeks to expand the supply chain's capacity to respond quickly to a change in demand [5]. The occurrence of events that cause disruption to the supply chain, even if these events take place far away, can create disruptions on a large scale. These disruptions can ripple through the supply chain and lead to many negative effects. If the supply chain's activities cannot manage disruptions well, it will be faced will potentially negative consequences, which in turn increases the risk of continued forecast of the business [6] and leads financial losses that cannot be compensated. Pandemics, economic recession, and more remind us that we live in a constantly changing and unpredictable world [7] and there is no way to eliminate the risks of and disruptions to the supply chains. To reduce the risk, supply chains must be multi-faceted and designed in a way that prepares them for any course of events, so that they are able to return to the original or even an improved stage after a disruption in addition to providing an effective and efficient response; this is what supply chain resilience means [8]. Overall, supply chains are vulnerable to disruption and a reduced cost, high qualities, a reduced lead time, and a higher level of service are not the only factors that determine their competitiveness. The ability to overcome various disruptions that could put the supply chain at risk is among important factors that determine supply chain competitiveness; therefore, supply chains must be resilient [9].

There are several factors in the supply chain that can increase resilience [10,11]. The concept of resilience in supply chain is still new, and there is a notable gap between expectations of scholars and experiences [12]. While resilience can be derived from a wide range of supply chain functions, strategies of collaboration, agility, flexibility, and redundancy are recognized as the most important capabilities to improve a company's response to supply chain resilience [13,14]. Shekarian and Mellat Parast [15] revealed that collaboration is the most important factor for managing control risk; a low level of collaboration and minimal flexibility have a great impact on supply chain resilience [16]. In addition, Wieland and Wallenburg [17] indicate that "communicative and cooperative relationships have a positive effect on resilience".

Yet, when faced with an uncertain environment, many companies choose alliances as a way of collaboration to reduce disruptions [18]. Alliances can increase the use of resources, learning, and development of corporate activities. Additionally, the communication network created by the alliance can moderate the unpredictability of the environment, increase predictability and flexibility, and provide adaptation to environmental changes [19]. Collaboration through alliances leads to sharing of information, equipment, and strategic plans and enables supply chain members to gain resilience [20].

Some articles have discussed how collaboration can influence supply chain resilience [4, $10,15]$, but no articles were found that reviewed the literature connecting strategic alliances and supply chain resilience. Therefore, it seemed necessary to conduct a comprehensive study to review and categorize all articles in this field using bibliometric analysis. This paper aims to concentrate on the subject of resilience and strategic alliances in supply chain. Thus, the following questions will be addressed in this research:

- What are the trends of research on Supply Chain Resilience and Strategic Alliances?

- What are the research gaps and how can scholars contribute to the field in future?

After the introduction, we review the literature. Then we have the methodology and bibliometric analysis section. After that, the discussion section concludes the findings paper. Practical implications will be the next section. Then, we have several suggestions for further research and, finally, we conclude the article.

\section{Methodology}

This study uses tools of bibliometric analysis to investigate publications in the field of supply chain resilience and strategic alliances. Bibliometric analysis is a research method that summarizes scholarly publications in quantitative terms, such as keyword analysis and frequency of article citations, to estimate the performance of authors, journals, and research institutions [21]. 
The literature has been collected from the Web of Science (WoS) database to ensure selection of a wide range of articles with the highest level of validity and reliability. Academic institutions and researchers use the WoS more than other databases for bibliometric analysis [22]. The WoS is one of the most significant scientific databases of research articles; it includes more than 12,000 assertive and brilliant academic journals from the SSCI and SCIE. Many academics and practitioners apply literature review based on this important database [23], and the WoS has widely been applied in a substantial amount of academic research. It not only is used as a research tool across different scientific areas but also as a dataset for large-scale data-intensive research [24]. Therefore, in this study, the WoS was selected as the scientific database in this study. Of course, there are other databases which can be considered as further studies in future academic research. The search indicators were specified as explained below:

- To study the evolution of the literature more extensively, the "all years" timespan was chosen. There are no limitations regarding to time span of searched publications; for that, we consider all relevant papers and provide a comprehensive exploring of the research in a wide time span, including all years of publications indexed in the WoS.

- $\quad$ All the English articles published on the WoS are included.

- After the literature scope was determined, eight leading experts and university professors in supply chain management have been invited to the Delphi panel and were consulted for identifying the keywords, as one of the main important steps in bibliometric studies is selecting the research keywords.

The keywords were categorized in the three following groups based on expert opinion and review of the literature:

1. Supply chain,

2. Alliances,

3. Words relevant to resilience, including resilience, flexibility, agility, redundancy, collaboration, inventory, integration, capacity, and financial strength.

For example: TS = (supply chain and alliance and flexible $\left.{ }^{*}\right)$

- After excluding redundant publications and irrelevant sources such as commentaries, book reviews, book chapters, and early access or proceeding papers, 518 publications related to supply chain resilience and strategic alliances were finally selected.

The articles' full-texts were studied; all of them presented an appropriate overview of the field of resilience and alliance in supply chains. Therefore, the analysis of the collected data began by using the Bibliometrix package accessible in $\mathrm{R}$ programming language. The $\mathrm{R}$ software provides many packages related to bibliometrics. Bibliometrix is one of them, which is an open-source tool mostly used for quantitative research in scientometrics tools. It is necessary to say that it includes all important bibliometric methods of related analysis. Bibliometrix is a singular tool, which has been developed for graphic R language and the statistical computing based on logical bibliometric workflow. $\mathrm{R}$ is also a functional programming language and an object-oriented one, so creating new functions is easy to do with it. Figure 1 shows the flow diagram of the methodology to obtain the data. 


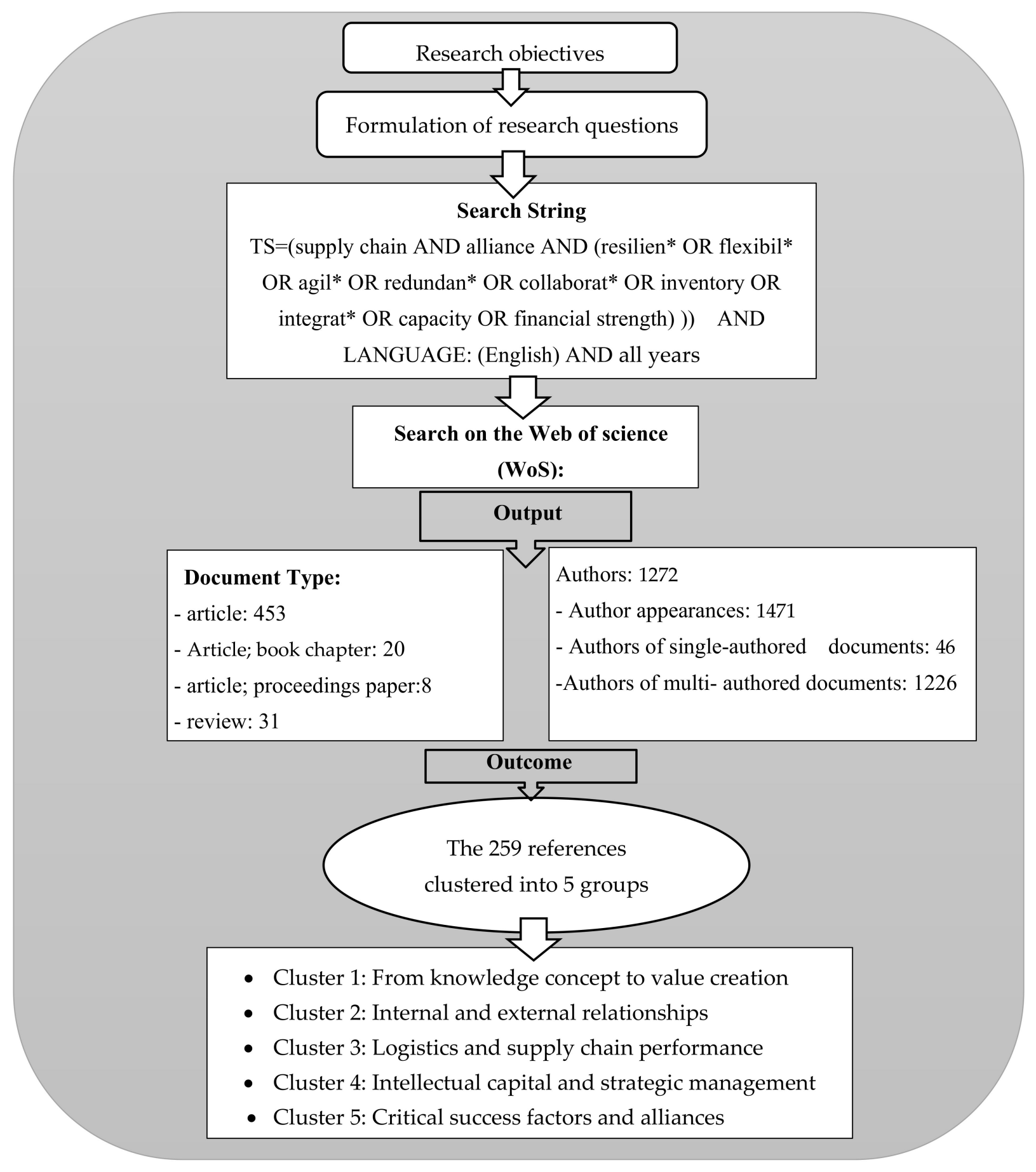

Figure 1. Research structure processes and flow diagram.

\section{Literature Review and Background}

\subsection{Supply Chain Resilience}

Supply chain includes a collective of people, processes, resources, and information that are responsible for turning raw material into products and delivering them to the customers. A supply chain generally consists of several stages that include customers, retailers, wholesalers, producers and suppliers of raw materials and machinery [25]. Every stage of a supply chain is connected to others through the flow of goods, information, and money; this exchange usually flows both ways [26].

Today's competitive market involves a high level of adaptability and uncertainty, which makes the supply chain even more vulnerable and leads to greater risks. At the 
same time, the issues of globalization, short life spans for products, and greater demand from customers have had undesired effects on the supply chain. In recent years, due to various events that have taken place, the topic of supply chain vulnerability and disruption has received immense attention. The managers of different organizations have reached the important conclusion to manage supply chains in such a way that they are responsive to change [27].

The first step to explaining resilience in the context of supply chain was taken by Rice and Caniato [28]: the ability to react to an unexpected disruption, such as a terrorist attack or a natural disaster, and return to the natural order. Nest, Christopher and Peck [29] and Sheffi and Rice [30] offered brief conceptions on the notion of supply chain resilience. Theoretically, perhaps the broadest definition of supply chain resilience is from Ponomarov and Holcomb [8]. They defined supply chain resilience as "The supply chain's adaptability to prepare for unexpected events, respond to disruptions, improve by maintaining operations on the desired communications level, and exert control on the structure and the operation". Grotsch et al. [31] suggested that supply chain risk management pursues the specific purpose of creating and maintaining a resilient supply chain. Accordingly, some studies show that supply chain resilience can create a sustainable competitive advantage and a more resilient supply chain by maintaining adaptability and expanding the required capacities.

Ja'farnejad and colleagues [32] started a study titled supply chain resilience in the medical equipment industry. The goal of this study was to find the key factors influencing the resilience and flexibility of the medical equipment supply chain, which plays a critical role in the functioning of the health system on a national level, and eventually examine and analyze the dynamic relations of these factors, use the Delphi method to identify the key factors in supply chain resilience, and analyze the relations between these factors using the dynamic system method.

Rajesh and Ravi [33] used the grey methodology to create a model for choosing a supplier and developing supply chain resilience. They selected an electronic supply chain with six alternative suppliers as a case study and, by calculating the grey possibility values for supplier selection, prioritized them. The qualities they took into consideration for a resilient supply included quality, cost, flexibility, speed, transparency, vulnerability, collaboration, risk awareness, persistency, technology, research and development, security, and environmental concerns.

Ambulkar et al. [34] studied how reconfiguration of resources and risk management infrastructure can affect the relations between different types of disruptions and companies' resilience. In this regard, they found that reconfiguration of resources plays a critical role when it comes to high-impact disruptions. Nonetheless, risk management infrastructure is also a key factor in responding to low-impact disruptions.

\subsection{Strategic Alliance}

With increasing uncertainty in the global atmosphere, companies have turned to strategic alliances to maintain their competitive advantages [35]. Strategic alliances have become an important part of the companies' global strategies and are used by commerce managers to achieve different strategic goals. Strategic alliances are voluntary agreements between companies that include the exchange, sharing, or shared development of products, technologies, or services. These alliances can have different types and occur on vertical or horizontal lines [36].

Businesses no longer act as independent entities due to their competitive nature; they compete by joining the supply chain alliance. Therefore, suppliers, producers, logistics companies, and retailers always form stronger horizontal or vertical alliances for competing in the supply chain. Immunization of technologies and critical knowledge, expansion of entries and shares in the market, and spreading out of costs and risks are the three main advantages to creating alliances in supply chains. An alliance is a flexible tool for learning, a method to transfer knowledge effectively among partners and join resources, and a way to realize technological potentials and other complex capacities [19]. 
When facing an uncertain environment, many companies seek alliances as a strategy to reduce their risk with the main stakeholders [18]. The alliance configuration capacity allows a company to choose its network of inter-organizational partnerships for confrontation with changing environmental conditions [37]. This capacity includes skills such as identification of valuable alliance opportunities, alliance design, alliance coordination, and alliance learning integration [38]. This ability allows the company to explore new markets with its new partners [39], shape the environment in response to changing customer needs by offering new products through strategic alliances, and stabilize the environment by using the alliance and creating a competitive advantage [40].

Although many alliance studies place emphasis on learning and relationship capital in creating competitive advantages, there is limited focus on the process of transferring resources and abilities, as well as integration [41]. Alliances can maximize the use of resources, learning, and development of companies' activities. Alliances are dependent on investments and relational structures that facilitate joint learning and provide advantages for cooperation and interaction. Factors determining success of alliances have a close connection with the network's capacity and a high level of trust among partners. Alliances can increase the chance for partners to enter novel technology fields, while the communication network created as the result of an alliance can also balance the unpredictability of the environment, increase the predictability and flexibility, and facilitate greater adaptability with the changing environment. Alliances can strengthen coordination and integration of inside and outside company processes and positively increase the value of partner companies [42].

\subsection{Strategic Alliance and Collaboration Influence over Supply Chain Resilience}

Collaboration means working together on a joint project. Since the resilient supply chain is a network, supply chain members must arrange all their forces to deal with a disruption when it appears. Thus, collaboration reduces mistrust and prepares the unit to deal with events. In addition, collaboration has been introduced as a glue that sticks the supply chain members together at times of disaster.

Collaboration prevents the opportunist behaviors of certain members that negatively affect the response capacity of the whole system. Coordination of decision-making is among the important factors in collaborating; eventually, collaboration is essential in terms of sharing the gained experiences among members after overcoming a crisis to better prepare for confronting future crises.

Supply chains need advanced abilities to oversee, report on, adjust, explore, and analyze all the events that have taken place. To be able to manage such events, there is a need to collaborate with partners and suppliers of goods and services. In the current competitive climate, all companies face numerous challenges, including supply chain disruptions, short lifespan of products, and natural and synthetic disasters. Yet, companies cannot respond alone to such challenges. They need to collaborate with their supply chain partners and beneficiaries to be more prepared to face such challenges. Entering the alliance and collaborating with the supply chain partners can help strengthen supply chain resilience. A main component of this collaboration is the sharing of information and data. Supply chains must become more resilient. Increased vision within the supply chain has become an important strategy for all companies. Observation in events related to supply chain partners, as well as the ability to respond and adjust, are among the features that shape a resilient supply chain. Long-term joint partnerships are considered to reduce such risks; therefore, companies need to focus on improving their cooperation, speed of interactions, and integrating the process with their supply chain partners. To create resilience, the business processes of all partners must be deeply intertwined. Information must flow among supply chain members smoothly and quickly. Communication is the main point since plans change, orders change, and the quality of information, production, inventories, and transportation directly affects the supply chain and must be discussed among partners. 
With the growth of supply chains across international borders, the requirement for supply chain members to abide by different laws in several countries. Trustworthy supply of materials is essential in all supply chains. In a resilient supply chain, suppliers must demonstrate the same characteristics presented by the central company. Supply chain members must be as predictable in abnormal times as they are in normal times. Many scholars have studied supply chain collaboration and its advantages since the 2000s [43,44]. Companies that collaborate can improve their business performance, boost their customer satisfaction, increase the market share, and gain more income while strengthening their positive relationship with supply chain partners. Collaboration can lead to development of implicit and explicit knowledge [45] to support the competitive advantage and stability of the supply chain. Banomyong [46] examined that collaboration between beneficiaries and alliance making can help build resilience in supply chains. He explored innovative ways like collective transportation, sharing profits, and stock economics to improve supply chain performance and strengthen supply chain resilience, and showed that sharing data plays an important role in supporting a close partnership between the beneficiaries.

\section{Bibliometric Analysis}

In this study, the bibliometric analysis is categorized into eight parts: (1) Year and Countries, (2) Types of journals, (3) Research areas, (4) Authors, (5) Affiliations, (6) Keywords, (7) Citations and (8) Reference co-citation.

Table 1 classifies the information extracted from the WoS with 518 documents between 1995 and 2021 (August 2021). These documents were published in 227 different sources. The keywords mentioned in the publications were about three times the number of publications, a total of 1127. A total of 1272 authors were identified, 46 of whom worked alone, while 1226 wrote their articles in collaboration with others.

Table 1. Main Information about the collection.

\begin{tabular}{cc}
\hline Description & Results \\
\hline Timespan & $1995-2021$ \\
Sources (Journals, Books, etc.) & 227 \\
Documents & 518 \\
Average years from publication & 7.12 \\
Average citations per documents & 35.63 \\
Average citations per year per doc & 3.637 \\
References & 2314 \\
article & 453 \\
Article; book chapter & 20 \\
Article; proceedings paper & 6 \\
Review & 31 \\
Keywords Plus (ID) & 1127 \\
Author's Keywords (DE) & 1694 \\
Authors & 1272 \\
Author Appearances & 1471 \\
Authors of single-authored documents & 46 \\
Authors of multi-authored documents & 1226 \\
Single-authored documents & 46 \\
Documents per Author & 0.407 \\
Authors per Document & 2.46 \\
Co-Authors per Documents & 2.84 \\
Collaboration Index & 2.6 \\
\hline
\end{tabular}

\subsection{Distribution of Articles Based on Year and Country}

The number of publications at different times is used in this study to indicate the trend in research. Although the concept of resilience was first introduced in the 1970s [22], literature on strategic alliances in the supply chain regarding resilience was not published until 1995. The number of articles before 2005 was very limited; publications have increased 
significantly since 2016. According to Figure 2, the results show a rapid growth in the rate of publications in recent years. Articles are classified based on the corresponding author's country, and as reported in Table 2, China, the United States (US), and the United Kingdom have the highest number of scientific productions and citations in this field. The US has a collaboration network with countries such as Australia, Brazil, Iran, Korea, and Switzerland. The United Kingdom also collaborates with Italy, Germany, Poland, Austria and Ireland to publish articles.

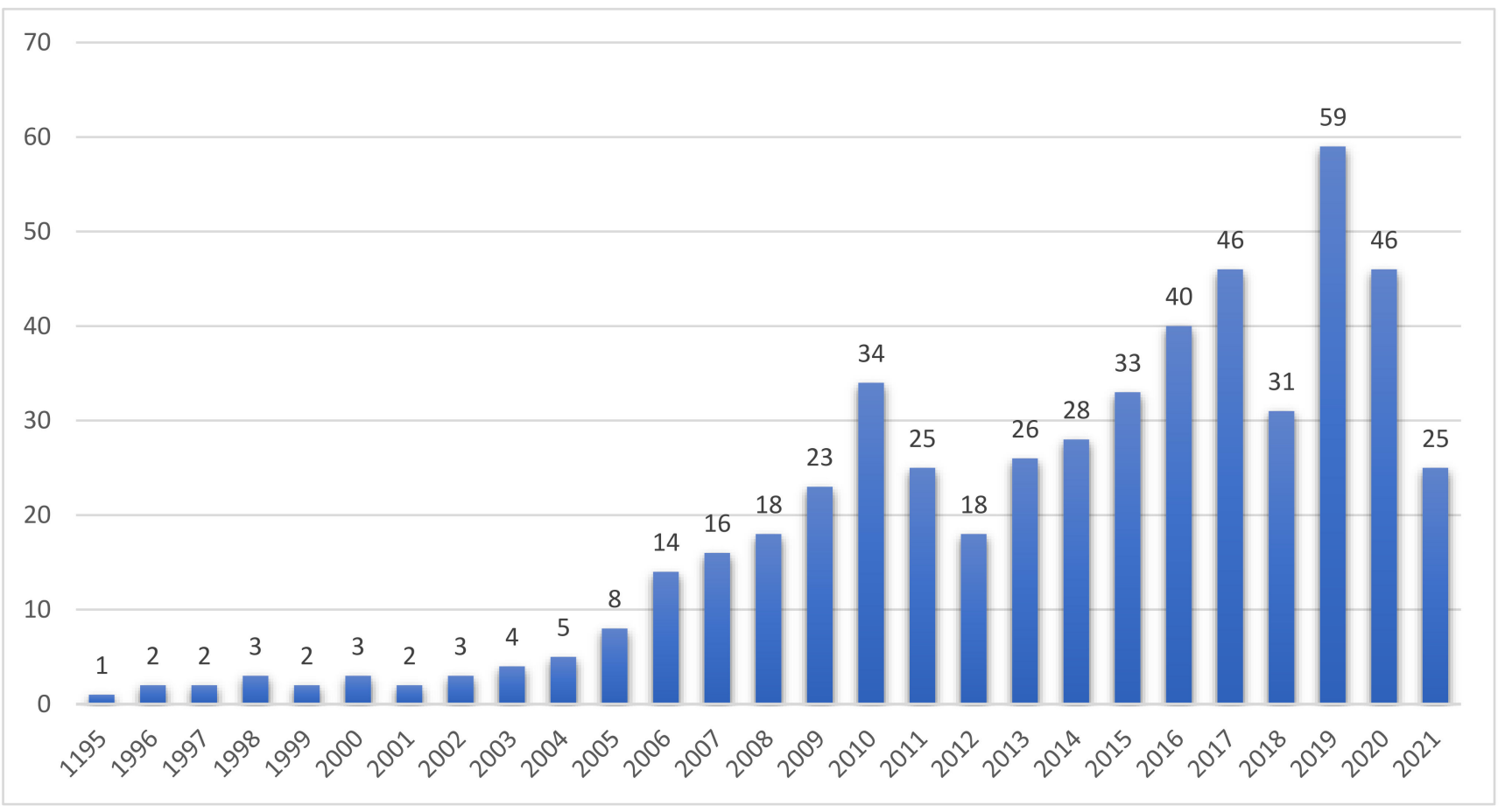

Figure 2. Distribution of articles published over time.

Table 2. Most publications and most total citations in different countries.

\begin{tabular}{cccc}
\hline & Number of Publication & Country & Number of Total Citations \\
\hline China & 396 & USA & 8303 \\
USA & 393 & China & 2660 \\
UK & 172 & United Kingdom & 1657 \\
Netherlands & 55 & Australia & 729 \\
Spain & 53 & Spain & 434 \\
Australia & 52 & India & 337 \\
Italy & 48 & Netherlands & 298 \\
Germany & 43 & Canada & 301 \\
India & 47 & Ireland & 293 \\
Canada & Korea & 269 \\
France & 34 & Germany & 294 \\
South Korea & 30 & Italy & 157 \\
Finland & 29 & Poland & 144 \\
Brazil & 27 & South Africa & 127 \\
Iran & 21 & Malaysia & 126 \\
New Zealand & 21 & France & 110 \\
South Africa & 17 & Finland & 96 \\
Belgium & 17 & Switzerland & 76 \\
Malaysia & 16 & Belgium & 68 \\
Ireland & 15 & Chile & \\
\hline
\end{tabular}




\subsection{Publications by Journal}

In order to evaluate the influence and impact of different journals in this field, the number of publications of each journal was calculated. As Table 3 shows, the top four journals cover the highest number of articles. The 518 articles reviewed in this study have been published in 227 different international scientific journals in the field of operation management. Of those, 232 articles were published in 20 journals, which can be seen in Table 3 . The analysis demonstrates that the highest number of articles has been published in the "International Journal of Production Economics", the "International Journal of Production Research", "Supply chain Management—an International Journal", "Sustainability", and "Journal of Operations Management". Figure 3 shows the increasing number of articles published in these five journals by year.

Table 3. Distribution of publications in top 20 journals.

\begin{tabular}{cc}
\hline Sources & Articles \\
\hline International Journal of Production Economics & 28 \\
International Journal of Production Research & 24 \\
Supply Chain Management-An International Journal & 23 \\
Sustainability & 20 \\
Journal of Operations Management & 15 \\
International Journal of Logistics Management & 14 \\
International Journal of Operations $\backslash$ \& Production Management & 13 \\
Industrial Marketing Management & 12 \\
European Journal of Operational Research & 10 \\
Journal of Cleaner Production & 12 \\
Production and Operations Management & 8 \\
Industrial Management $\backslash \&$ Data Systems & 7 \\
Journal of Purchasing and Supply Management & 7 \\
Decision Sciences & 6 \\
Journal of Business $\backslash \&$ Industrial Marketing & 6 \\
Management Science & 6 \\
Technovation & 6 \\
\hline Production Planning $\backslash \&$ Control & 5 \\
\hline
\end{tabular}

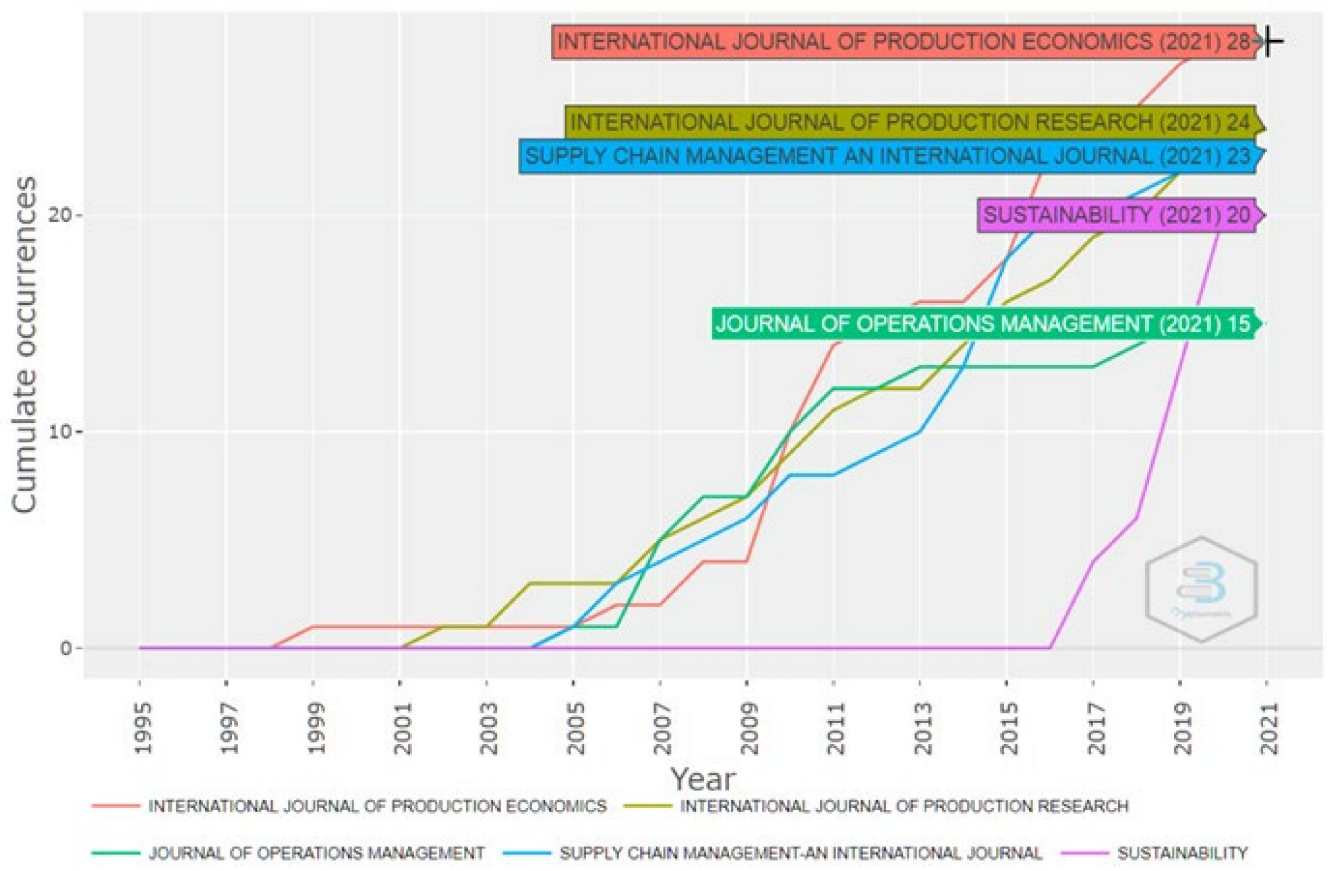

Figure 3. Source growth. 


\subsection{Research Areas}

The analysis of research areas and subject co-occurrence helps to explore disciplines that play a part in the expansion of a certain knowledge area [47]. Figure 4 shows the network of research areas based on the field of study. The analysis demonstrates that the 518 articles can be divided into 72 categories. As shown in Figure 4, the top-5 categories are "Management", "Operations Research \& Management Science", "Business", "Industrial Engineering", and "Manufacturing Engineering". These results demonstrate that this field of research is an interdisciplinary subject. Research is interested in the perspective of "business", "economics" "operations research and management science", "engineering", and "computer science" to study alliances and resilience. The field can also be studied from other perspectives, including "environmental sciences", "green sustainable science technology", and "transportation".

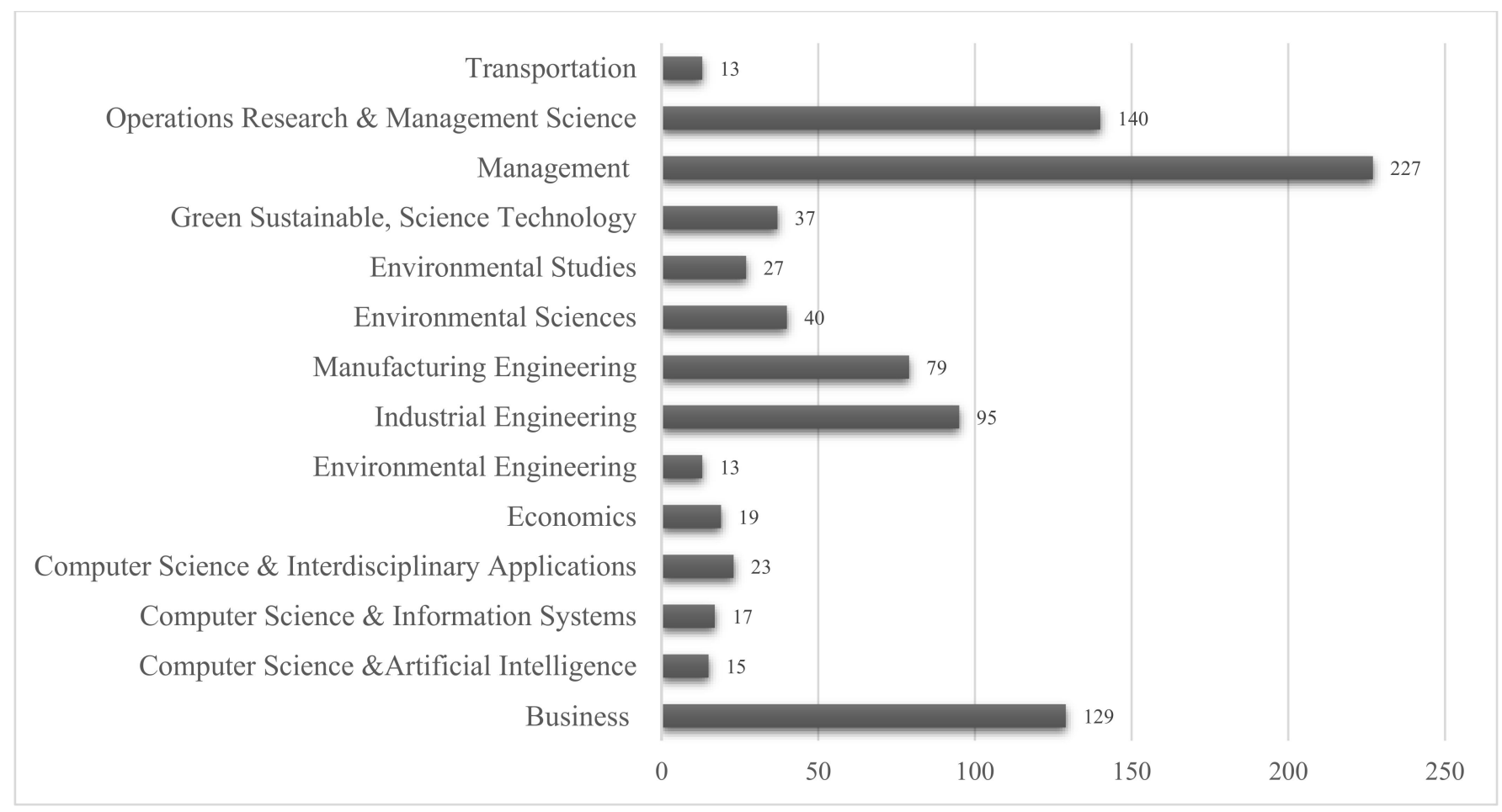

Figure 4 . Subject category with more than 10 articles.

\subsection{Influence of Authors}

According to data analysis, there are 1272 scholars in this field, 1124 (88\%) of whom published only one article. The results reveal that Baofeng Huo and Zach G. Zacharia are the most productive researchers in this field since each has published seven and five papers, respectively. Table 4 demonstrates the most contributing authors in this area, with the number of their publications and the top-20 influential scholars identified by their citations. The results show that Robert B. Handfield is the most influential author regarding citation numbers; he has made a significant contribution to the improvement of this field, and is also the only scholar whose citations count over 1000, which shows that his publications are very important and have a great influence on other researchers. 
Table 4. Major authors in this field.

\begin{tabular}{|c|c|c|c|c|c|c|}
\hline Author & H-Index & G-Index & M-Index & Total Citation & Number of Publication & Publication Years \\
\hline Huo, B. & 4 & 6 & 0.667 & 78 & 7 & From 2016 to 2021 \\
\hline Zacharia, Z.G. & 5 & 5 & 0.227 & 515 & 5 & From 2000 to 2021 \\
\hline Barnes, D. & 4 & 4 & 0.308 & 198 & 4 & From 2009 to 2021 \\
\hline Cheng, T.C.E. & 4 & 4 & 0.267 & 702 & 4 & From 2007 to 2021 \\
\hline Handfield, R.B. & 4 & 4 & 0.167 & 1731 & 4 & From 1998 to 2021 \\
\hline Iyer, K.N.S. & 4 & 4 & 0.500 & 39 & 4 & From 2014 to 2021 \\
\hline Wang, J. & 3 & 4 & 0.429 & 47 & 4 & From 2015 to 2021 \\
\hline Wang, $\mathrm{X}$. & 3 & 4 & 0.750 & 66 & 4 & From 2018 to 2021 \\
\hline Wang, Y. & 2 & 4 & 0.167 & 69 & 4 & From 2010 to 2021 \\
\hline Zhang, Y. & 2 & 4 & 0.125 & 39 & 4 & From 2006 to 2021 \\
\hline Bruccoleri, M. & 3 & 3 & 0.375 & 36 & 3 & From 2014 to 2021 \\
\hline Childerhouse, P. & 3 & 3 & 0.500 & 36 & 3 & From 2016 to 2021 \\
\hline Choi, T.Y. & 3 & 3 & 0.214 & 618 & 3 & From 2008 to 2021 \\
\hline Deshmukh, S.G. & 3 & 3 & 0.231 & 166 & 3 & From 2009 to 2021 \\
\hline Fawcett, S.E. & 3 & 3 & 0.300 & 193 & 3 & From 2012 to 2021 \\
\hline Huang, G.Q. & 3 & 3 & 0.273 & 80 & 3 & From 2011 to 2021 \\
\hline Jean, R.B. & 3 & 3 & 0.250 & 203 & 3 & From 2010 to 2021 \\
\hline Lai, K.H. & 3 & 3 & 0.200 & 664 & 3 & From 2007 to 2021 \\
\hline Liu, C. & 3 & 3 & 0.500 & 70 & 3 & From 2016 to 2021 \\
\hline Liu, W. & 2 & 3 & 0.333 & 29 & 3 & From 2016 to 2021 \\
\hline
\end{tabular}

Furthermore, the collaboration between different scholars shows a network of effective research groups in the field. Co-author analysis is known as a way to determine patterns of collaboration in a field and the network of researchers and relationships among them [48]. The collaboration network analysis shows that there is a significant amount of co-authorship in this field. As Figure 5 shows that the most significant collaborations are between Huang, $\mathrm{Gu}$, and Chen; between Huo, Wang, and Childerhouse; and between Liu, Si, and Xie.

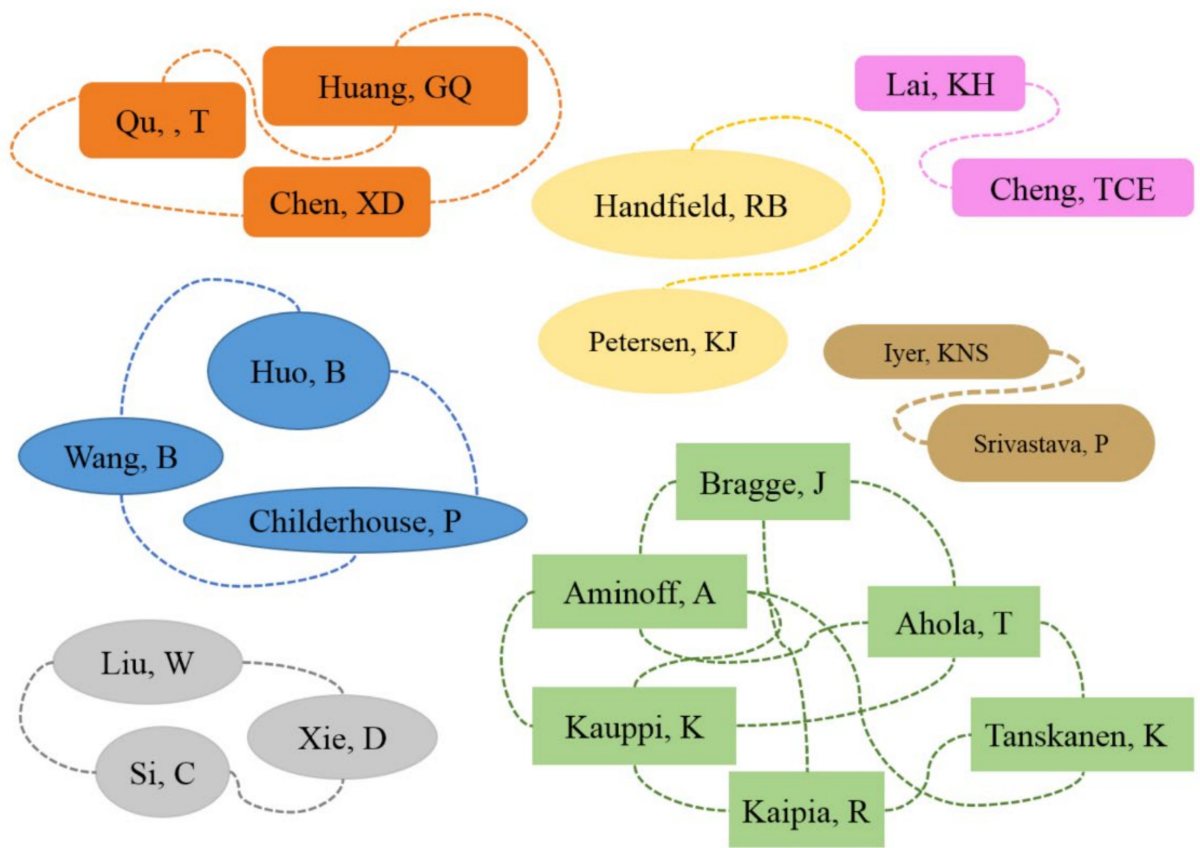

Figure 5. Co-author analysis.

\subsection{Affiliation Analysis}

Table 5 illustrates the top-20 organizations ranked by the number of publications. The results show that articles have been published around the world, from Hong Kong to United 
States or Taiwan and so on. The most influential organization with 20 publications was The Hong Kong Polytechnic University. The other four organizations that comprised the top-5 are the Arizona State University (17), The University of Manchester (15), National Taiwan University of Science and Technology (13) and South China University of Technology (13).

Table 5. Top 20 institution regarding to the number of publications.

\begin{tabular}{ccc}
\hline Institution & The Number of Publication & Country \\
\hline The Hong Kong Polytechnic University & 20 & Hong Kong \\
Arizona State University & 17 & United States \\
The University of Manchester & 15 & United Kingdom \\
National Taiwan University of Science & 13 & Taiwan \\
and Technology & 13 & China \\
South China University of Technology & 12 & United States \\
Michigan State University & 10 & China \\
Tsinghua University & 11 & China \\
Zhejiang University & 10 & China \\
Tianjin University & 10 & China \\
Tsinghua University & 10 & United States \\
University of Tennessee & 9 & Australia \\
Monash University & 9 & Taiwan \\
National Taiwan University & 9 & Hong Kong \\
The University of Hong Kong & 9 & United Kingdom \\
University of Warwick & 9 & Netherlands \\
Vrije Universiteit Amsterdam & 8 & Finland \\
Aalto University & 8 & United Kingdom \\
Coventry University & 8 & United States \\
Florida State University & 8 & United States \\
Georgia State University & &
\end{tabular}

\subsection{Keywords Analysis}

Analysis of the 518 publications concludes with 1127 keywords. Figure 6 summarizes the major keywords and the top- 5 as reported in Table 6 are performance, alliance, management, strategic alliance, and integration.

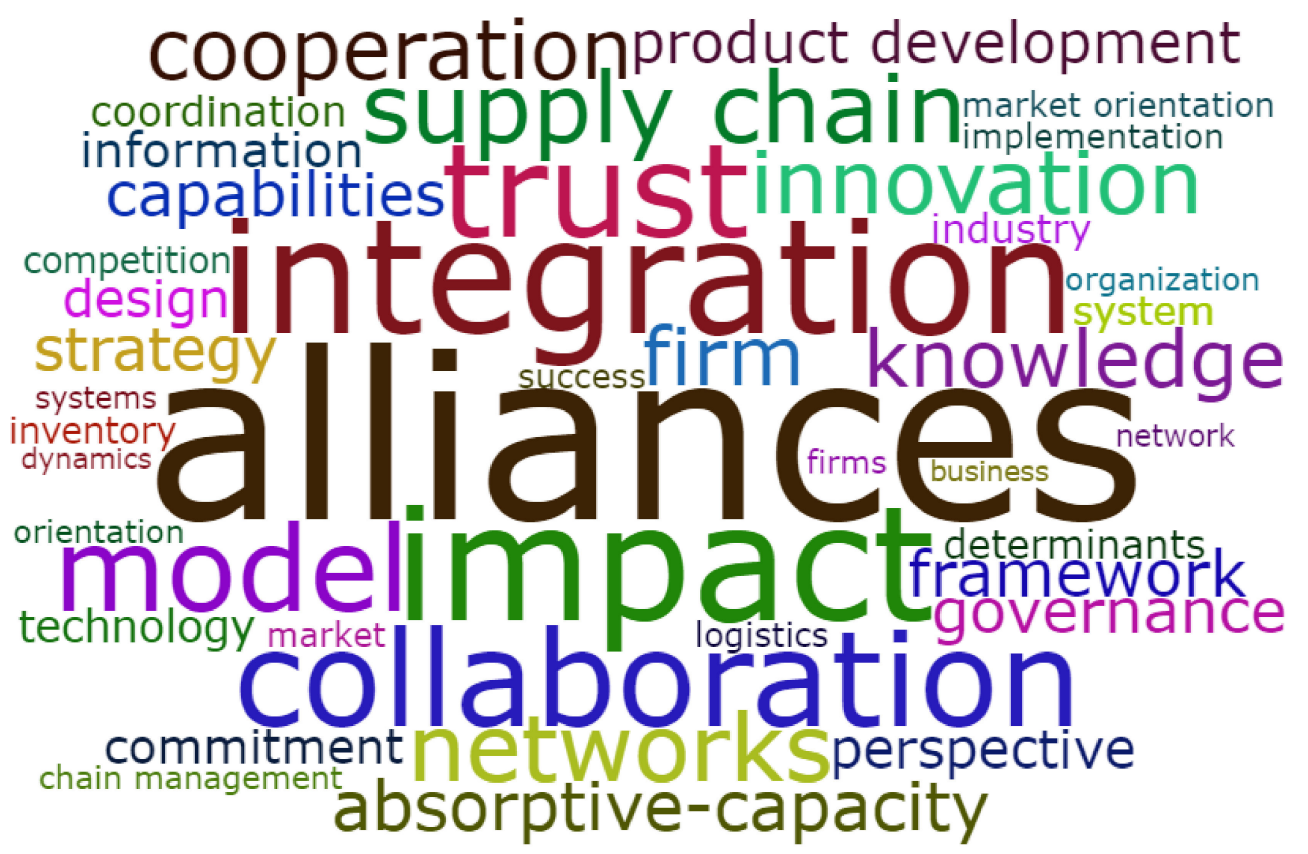

Figure 6. The major keywords. 
Table 6. Top ten keywords.

\begin{tabular}{ccccccc}
\hline Keywords & 1996-2000 & 2001-2005 & 2006-2010 & 2011-2015 & 2016-2021 & Total \\
\hline Performance & 0 & 2 & 28 & 46 & 68 & 144 \\
Alliances & 4 & 6 & 39 & 23 & 46 & 118 \\
Management & 2 & 4 & 27 & 32 & 48 & 113 \\
Strategic alliances & 1 & 1 & 15 & 25 & 40 & 82 \\
Impact & 1 & 1 & 11 & 21 & 47 & 81 \\
Integration & 4 & 3 & 23 & 25 & 35 & 80 \\
Trust & 3 & 3 & 22 & 17 & 22 & 67 \\
Collaboration & 0 & 3 & 14 & 11 & 36 & 66 \\
Model & 0 & 2 & 10 & 12 & 35 & 59 \\
Supply chain & 1 & 1 & 8 & 6 & 33 & 49 \\
\hline
\end{tabular}

Figure 7 shows the change in research topics throughout time. In the late 20th century, for example, "alliance" and "integration" were the most popular keywords in this field of study. Between 2006 and 2016, however, the increasing use of keywords of "performance", "management" and "strategic alliance" signals a higher interest in these topics, and from 2012 onward, research about "collaboration" has become more popular.

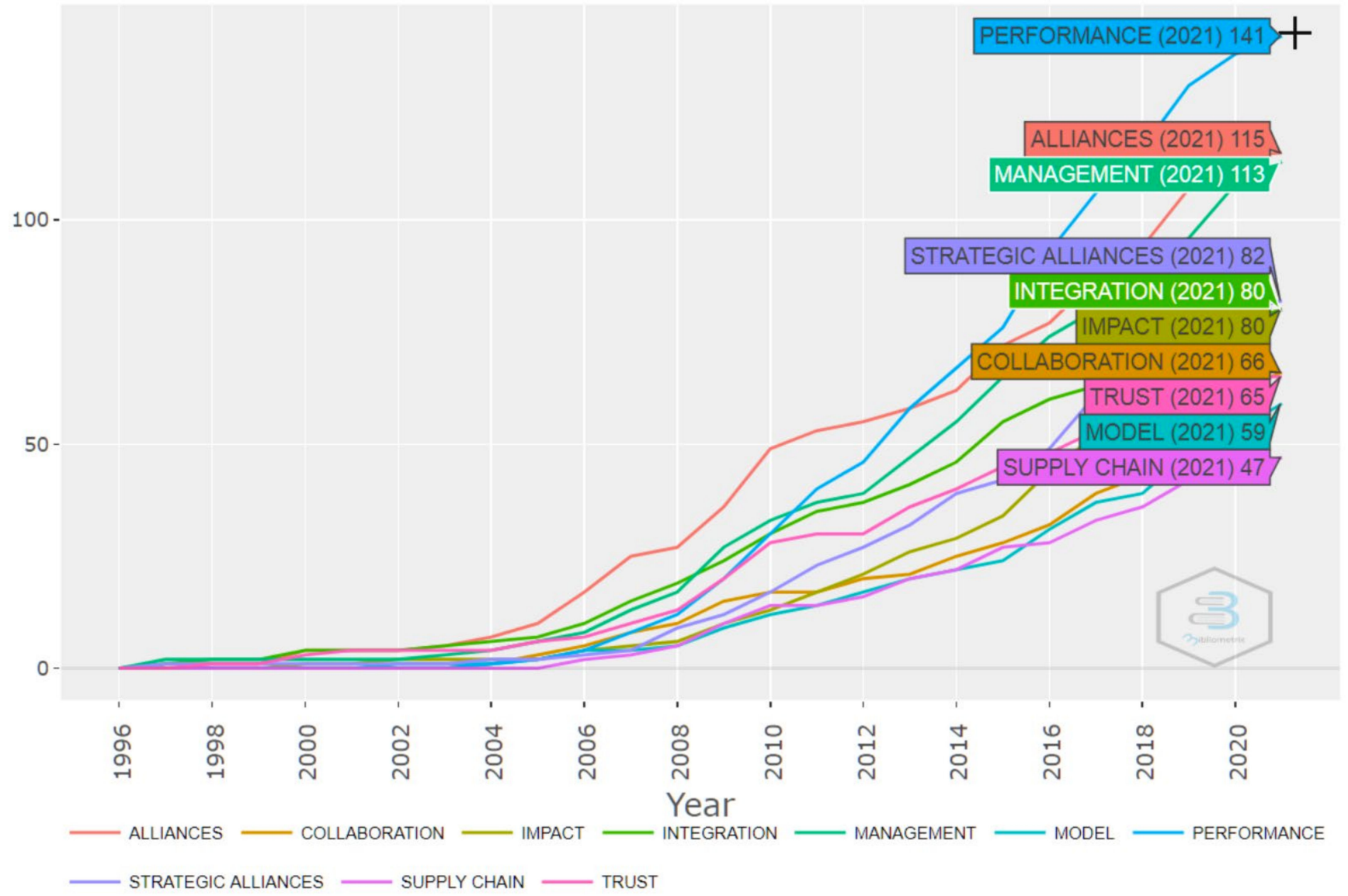

Figure 7. Annual keywords growth in research topic.

\subsection{Citations Analysis}

Citation analysis focuses on the popularity of a study based on the number of citations it receives [49,50]. Citations on both a local and a global scale are measures for citation analysis. Local citations refer to citing of an article in this collection by other papers in this 518-member group, while global citations include the total number of citations from all scientific literature. 
Table 7 shows the top-10 articles regarding local and global citations. The article with the highest number of local citations from Petersen et al. (2005) [51], published in the "Journal of Operations Management"; Handfield, who was the most influential author with the highest number of total citations, is a main author of this article.

Table 7. Top 10 publications regarding to local citations.

\begin{tabular}{ccc}
\hline Author (Year) & Local Citation & Global Citation \\
\hline Petersen et al. (2005) [51] & 16 & 627 \\
Krause et al. (2007) [52] & 26 & 606 \\
Paulraj et al. (2008) [53] & 22 & 548 \\
Nyaga et al. (2010) [54] & 21 & 468 \\
Villena et al. (2011) [55] & 17 & 450 \\
Monczka et al. (1998) [56] & 15 & 404 \\
Li and Lin (2006) [57] & 16 & 377 \\
Gunasekaran et al. (2008) [58] & 13 & 373 \\
Ireland and Webb (2007) [59] & 20 & 322 \\
Power (2005) [60] & 18 & 295 \\
\hline
\end{tabular}

Citation analysis uses citation frequencies to determine the popularity of a research paper [61,62]. Brin and Page [63] declare that "PageRank is a scientific and popular ranking algorithm to measure both the popularity and prestige of a certain node in a cited network. It was first presented for application on the Google search engine to recommend higher quality web pages to consumers". As Table 8 shows, the top-4 articles based on PageRank are Krause et al. (2007), Villena et al. (2011), Paulraj et al. (2008), and Lawson et al. (2008); these results are consistent with both local and global citations (see Table 7).

Table 8. Top 10 articles regarding to PageRank analysis.

\begin{tabular}{cc}
\hline Author (Year) & Page Rank \\
\hline Krause et al. (2007) [52] & 0.00748428 \\
Villena et al. (2011) [55] & 0.005182867 \\
Paulraj et al. (2008) [53] & 0.005166436 \\
Lawson et al. (2008) [64] & 0.005047595 \\
Nyaga et al. (2010) [54] & 0.004826402 \\
Ireland and Webb (2007) [59] & 0.004772597 \\
Petersen et al. (2005) [51] & 0.004402508 \\
Cheng et al. (2008) [65] & 0.002389084 \\
Koufteros et al. (2007) [66] & 0.001368145 \\
Boddy et al. (2000) [67] & 0.000981456 \\
\hline
\end{tabular}

\subsection{Reference Co-Citation Analysis}

Reference co-citation analysis includes a collection of edges and references that point to the number of reference co-occurrence in the set of papers [68]. Put otherwise, reference cocitation refers to a situation when two articles are cited together by another publication [68]. Reference co-citation analysis demonstrates the growth and evolution of a certain subject area [69]. It is also useful for academics who study a subject area in order to find new opportunities for research [70]. There are five clusters of literature detected by reference co-citation analysis.

Table 9 shows that 259 references out of 22,154 were co-cited more than 10 times in the published research. The article by Dyer and Singh (1998) is the biggest node, which points to being most frequently co-cited in this area of study. This paper was published in Academy of Management Review Science and made a significant contribution to development of research in the field. The article was considered one of the most popular in the field of "cooperative strategy and sources of inter-organizational competitive advantage" based on its local citations and PageRank score. 
Table 9. Leading co-cited references of each cluster.

\begin{tabular}{|c|c|c|c|c|}
\hline Cluster 1 & Cluster 2 & Cluster 3 & Cluster 4 & Cluster 5 \\
\hline Grant (1996) [71] & Vachon and Klassen (2008) [72] & Ragatz et al. (2002) [73] & Adler (2002) [74] & Anderson and Narus (1990) [75] \\
\hline Kogut et al. (1992) [76] & Fornell and Larcker (1981) [77] & Carr (1999) [78] & Autry et al. (2008) [79] & Das and Teng (2001) [35] \\
\hline Tranfield et al. (2003) [80] & Jap (1999) [81] & Dyer (1996) [82] & Benton and Maloni (2005) [83] & Mamédio et al. (2019) [19] \\
\hline Dyer and Singh (1998) [88] & Paulraj et al. (2008) [53] & Frohlich and Westbrook (2001) [89] & Carey et al. (2011) [90] & Kumar et al. (1995) [91] \\
\hline Hamel (1989) [92] & Podsakoff et al. (2003) [93] & Lee et al. (1997) [94] & Coleman (1988) [95] & Lusch and Brown (1996) [96] \\
\hline Lavie (2006) [97] & Sarkar et al. (2001) [98] & Mentzer et al. (2001) [99] & Cousins and Menguc (2006) [100] & Mayer et al. (1995) [101] \\
\hline Teece (1986) [102] & Wittmann et al. (2009) [103] & Womack et al. (1990) [104] & Inkpen (2005) [105] & Miles and Huberman (1994) [106] \\
\hline Gulati et al. (2000) [112] & Nunnally and Bernstein (1994) [113] & Clark (1989) [114] & Krause et al. (2007) [55] & Zaheer et al. (1998) [115] \\
\hline
\end{tabular}


The 259 references can be clustered into 5 groups, where the top-10 co-cited references in each cluster could be used to distinguish different research focuses, as shown in Table 9. Based on the content analysis of the articles, each cluster is categorized as follows:

- Cluster 1: From knowledge concept to value creation;

- Cluster 2: Internal and external relationships;

- Cluster 3: Logistics and supply chain performance;

- Cluster 4: Intellectual capital and strategic management;

- Cluster 5: Critical success factors and alliances.

\section{Discussion}

Analysis of available content in strategic alliances shows that nowadays, most businesses no longer act as independent institutions due to competitiveness, but compete through creation of alliances in the supply chain. Conversely, the level of resilience and the supply chain's capacity to overcome incidents and disruptions is unpredictable and its goal is to prevent the supply chain from moving towards undesirable conditions.

The results of the analysis of year-to-year trends in a number of articles show that although article numbers have been fluctuating, they experience an overall upward trend. Supply chains play an important role in the economic and social development of countries nowadays; in today's business world, they must be able to react appropriately when facing with unexpected turbulence and increase their resilience. Besides, strategic alliances have received increasing attention from scholars as an innovative way to improve companies' competitive capacity. Strategic alliances are vital due to competition in a knowledge-based economy and there are many strategic alliances formed in different industrial sections every year. Therefore, given the constantly increasing complexities of this world and knowledge sharing among companies, it appears that an increase in research in this field has not been unexpected; these two fields have received serious attention from universities and scholars for several years.

The country analysis puts China in the first place with 396 articles, and the US in second position with 393. A country citation analysis also puts the US and China in first and second place, with 8303 and 2660 citations, respectively, which shows the two have not only been pioneers in article production, but actually produced high-quality articles. Since strategic alliances are becoming one of the most important organizational forms in the US and other major economies (Dyer et al., 2008), the US and China seem to be paying an increasing attention to the topic given their status as the world's two greatest economies in terms of GDP.

The Hong Kong Polytechnic University ranks first with 20 articles and the Arizona State University ranks second with 17 articles published in this field.

The studies were published in 227 journals overall, and the International Journal of Production Economics ranks first in terms of the high number of published articles. This Journal is an indexed journal in Elsevier's Science Direct that publishes credible scientific articles in fields relevant to engineering and management. The high number of papers published in this top journal, with a Q1 quality and 5.134 impact factor, points to the significance of the topic for the journal.

Overall, 1272 authors were identified, among which Huo and Zacharia published the greatest number of articles. Based on the citation analysis, the article by Petersen et al. (2005) received the most citations. Handfield is identified as the most influential scholar with 1731 citations for four articles. According to Table 7, it can be said that the top-10 articles in terms of citations were published around topics of integrity, coordination, cooperation, and communication among members of the supply chain, especially between the buyer and the supplier.

Furthermore, the keyword analysis shows that "performance", "alliance", and "management" have been among the most frequently used keywords. The result is not unexpected since these words emphasize the common ground of research in this field and are considered an important and common topic of discussion in literature. 
Based on a reference co-citation analysis, five cluster groups are offered for 259 references that include, "From knowledge concept to value creation", "Internal and external relationships", "Logistics and supply chain performance", "Intellectual capital and strategic management", and "Critical success factors and alliances". Cluster 1 studies have paid attention to knowledge and value creation with strategic alliances. Grant et al. [71] expressed that, given the attributes of knowledge, organizations are looking to integrate knowledge such that they can share their expertise through strategic alliances and use each other's professional knowledge to create values. Lavie [84] also emphasizes the role that trust and knowledge sharing play in creating shared values among partners and claims that value creation through making of a strategic alliance can improve the organizational performance. In this cluster, there is also an emphasis on concepts of cooperation and integrity, which are among the key elements of supply chain resilience.

In the Cluster 2 studies, there is a general focus on the role of internal and external connections in creating cooperative relations and alliances in the supply chain. Connections are known as a critical factor in improvement of strategic alliances among organizations.

Companies are usually establishing internal and external connections with their partners in the supply chain to achieve efficiency, flexibility, and a sustainable competitive advantage [52]. For example, Paulraj et al. [53] concluded that inter-organizational connections improve buyers' and suppliers' performances. Moreover, Nyaga et al. [54] suggested that cooperative activities such as information sharing, attempt to create shared internal and external relationships, and shared investments lead to a rise in trust and commitment levels, which in turn lead to greater satisfaction and improved performance. A high level of mutual trust-inducing behaviors can lead to increased relative resilience in buyer-supplier relationships [8]. Yet, information sharing works as an incentive for cooperation and supply chain resilience, since cooperation only happens when every member can effectively receive the relevant information [116].

Cluster 3 articles pay attention to the logistics and performance of the supply chain. This cluster generally talks about improving the performance of the logistics system, integrating logistics systems with an approach to cut the cost, and designing inter-sectional cooperation systems based on long-term connection. Strategies suggested in this cluster of literature have been in line with one or a combination of the concepts of just-in-time manufacturing, performance boost, the bullwhip effect, cost reduction, service quality, and logistical alliance; it can be said that focus on these factors will improve resilience in the supply chain.

Cluster 4 focuses on intellectual capital and strategic supply chain management. When forming strategic alliances, organizations usually share not only capital resources, but also managers, workers, products, intellectual capital, and the technical knowledge of management. Intellectual capital in an organization and organizational characteristics are among the important motives behind development of stable and resilient companies [29].

Articles in Cluster 5 generally focus on key factors in strategic alliances, including trust, control, commitment, and risk. For example, trust can be generally said to have a positive effect on the functioning of strategic alliances, especially since existence of trust reduces the risk of opportunistic behaviors, eliminates the need for establishment of systems and control procedures with a high degree of formality and low flexibility, and hence leads to a reduction in the costs of transactions [117].

\section{Sub-Areas of Supply Chain Resilience}

One of the most critical supply chain disruptions in history that has challenged practitioners and scholars to improve supply chain resilience has been the COVID-19 pandemic [118]. A company that utilizes highly collaborative relationships with its key suppliers and customers (i.e., relational capital) while administering a well-integrated business process (i.e., structural capital) and providing its employees with high-level skills and abilities (i.e., human capital) can increase the resilience of its supply chain, allowing it to control the negative impact of a major disruption such as the COVID-19 pandemic [119]. 
The concept of intellectual capital (IC) in supply chain resilience has seen a growth in terms of the rate of publications in recent years. Companies with a higher level of IC have demonstrated significantly better levels of supply chain resilience compared to those with lower levels of IC [119].

Blockchain technology is the potential solution for augmenting supply chain resilience. With blockchain technology, shared data of a network are presented in an encrypted format, creating an extra layer of protection when it comes to data security, which is a potential benefit of improving resilience against recurring disruptions in the 'physical' and 'digital world' [120].

Inter-organizational relationships contribute to supply chain resilience. Connectivity, collectivity and scalability are key factors that shape inter-organizational and how they affect supply chain resilience. These mechanisms are driven by information sharing, decision synchronization, and incentive alignment to strengthen elements of self-organization, emergence, adaptation, and coevolution by adjusting and improving resilience strategies and practices [121].

Reporting on Corporate Social Responsibility (CSR) has been receiving greater attention in the construction industry as an effective tool to communicate social citizenship. Despite this increasing attention on the role of the construction industry in disaster resilience, CSR reporting on resilience issues among construction practitioners remains relatively unexplored [122].

\section{Current Gaps and Future Research Directions}

In this section, areas relevant to resilience and supply chain alliance that need greater attention from scholars are suggested as appropriate for future research programs. Given all the research, we can answer the question of "How can a supply chain become resilient through strategic alliances?" in future. Below are our suggestions for future research in this field:

1. Given that cooperation and connection-making in the supply chain are considered the most important step to bring the supply chain to a resilient stage $[29,123]$, and since the concept of alliance derives from cooperation, future research must focus on improving cooperation, speed of transactions, and integration of the process with supply chain partners through strategic alliances to attain resilience. Future research can also study the effects of strategic alliances between suppliers and producers on the manufacturing process of the final product used by the customers or the services offered to the customers to increase supply chain resilience. In addition, studying the strategic alliance between competitors in the supply chain is also valuable; for example, creating a strategic alliance through exchanging, sharing, or shared developing of products, technologies, or services among rivals can improve supply chain resilience.

2. As can be seen in Figure 4, many studies have taken an interdisciplinary approach and focused on five main areas of operations research and management, management science, business, industrial engineering, and manufacturing engineering. In future research, therefore, a more diverse group of fields can be used. For instance, even though the field of transportation is important for confronting and responding to disruptions in the supply chain, little research has been done in this area. Future research could investigate how creating strategic alliances in the supply chain's sphere of logistics and transportation can improve resilience. Moreover, to reduce disruptions in transportation and create better resilience in supply of resources, the design of effective, efficient, and flexible mechanisms in transportation via creation of strategic alliances should be researched. Furthermore, some of the fields that are not mentioned in Figure 4 can be studied in the future. In the field of psychology, for example, future research can ask how developing strong and effective decision support systems for supply chain allies can improve resilience when facing untrustworthy suppliers, an uncertain request, or disruption based on different attitudes such as optimism, pessimism, or opportunism. 
3. Considering the results of the reference co-citation analysis, five clusters were identified in literature including "From knowledge concept to value creation", "Internal and external relationships", "Logistics and supply chain performance", "Intellectual capital and strategic management", and "Critical success factors and alliances"; each could create a certain research potential in the future. Noting the articles in Cluster 1 , it can be said that knowledge sharing and creation of values through it is very important for creating a stable relationship among partners; future research can study the effect of exchanging knowledge and resources through creation of strategic alliances on improving supply chain resilience. Cluster 2 literature can be expanded by studying how and to what extent internal and external supply chain connections affect the resiliency of the supply chain. Based on articles in Cluster 3, future work can focus on creating alliances in the logistical and transportation field to increase supply chain resilience. Regarding Cluster 4, future research can discuss strategic suggestions on using intellectual capital to improve resilience and create alliances in the supply chain. Finally, Cluster 5 articles generally focus on key factors like trust, control, commitment, and risk in strategic alliances; so, future research can investigate how to bring about each factor in a strategic alliance and how they improve resilience.

4. Novel technologies to reduce the risk of disruption among supply chain members are so important that they have recently received an increasing amount of attention in different industries. Some studies have analyzed using novel technologies to reduce the risks of supply chain management and create resilient supply chains including meta-analyses [124] and Blockchain Technology [125]. Despite this, novel technologies have yet to improve in the field of supply chain resilience. Future research can focus on discovering how to design effective and resilient mechanisms for quick response and disruption recovery methods. For example, meta-data analysis can be used to offer solutions for supply chain allies to confront disruptions or even perhaps foresee the risk based on data trends. In addition, with increased trust and transparency among allies in the supply chain, the power and speed of response to disruptions can be increased with the blockchain technology, and supply chain resilience can be improved.

5. This article discussed a limited number of keywords in operation management. Given the complexities of strategic alliances in supply chains and resilience, taking a broader range of keywords, and stepping beyond operation management, would be a hopeful step in future studies.

Finally, there were limitations in this study that should be eliminated in future study. For example, the main data collection came from the WoS database. Scholars can also expand the database to include more publications from platforms such as Google Scholar or Scopus. Moreover, in these types of studies, a research team that is capable of a data-based analysis should be used; finding multi-purpose teams for collaboration on a dynamic analysis is difficult.

\section{Managerial Implications and Overall Recommendation}

Nowadays, the most important topic in supply chain management is facing various risks including operational, systemic, and relational risks. The findings of the present study show that the highest number of articles has been published in the field of management. This article tried to offer managers the opportunity to overcome supply chain disruptions and negative consequences of risks by becoming familiar with the concept and literature of resilience and create a non-stop flow of products in the entire network. The persistence of businesses and supply chains is guaranteed through communicating with partners and even competitors in the light of alliance. Managers can increase the precision, speed, and strength of dealing with risks and improve their supply chain performance.

Findings of the research in the cluster "From knowledge concept to value creation": Managers must not neglect knowledge fields and pay greater attention to knowledge management in their supply chain management since knowledge management and especially 
knowledge sharing is a key factor for improving interactions among supply chain members and can lead to greater supply chain resilience. In addition, given the importance of the knowledge management field in risk management, if knowledge is shared, resilience and value-making increases. Meanwhile, strategic alliances help the sharing of knowledge among two or more companies and knowledge sharing happens better in light of strategic alliances; thus, the two factors have a mutual relationship and by sharing knowledge between the alliance partners and even competitors, resilience can be strengthened.

Managers can pay attention to the integration of the supply chain to improve resilience and increase collaboration between suppliers and customers. Since strategic management is a main area of interest in directing organizations from managers' point of view and given the research results, strategic alliances can be noted in expanding entrepreneurial activities, especially organizational entrepreneurship, and shaping strategic collaboration networks in light of strategic alliances.

Findings of the research in the cluster "Internal and external relationships": one of the main principles of supply chains is relational management. Managers can promote the operational goals of the supply chain by creating strategic alliances and managing cooperative relationship. Noting the buyer-supplier relationship can especially help promote the cooperation levels and the intra-organizational cooperation that can bring a good result for the organization seeking the desired outcome. An axis of supply chain resilience is social responsiveness. Paying attention to resilience in public service and companies that provide public service increases social satisfaction and response and improves resilience. In light of this study, managers can correct their behaviors and pay attention to organizational behaviors that can improve internal and external connections.

Findings of the research in the cluster "Logistics and supply chain performance": Managers can produce higher quality products and confront technological uncertainties with greater preparation in light of supply chain cooperation and integration. Nonetheless, considering the issue of specialized supply networks can bring competitive advantages to the managers. Therefore, managers are advised to expand specialized supply networks and move in the direction of specialized activities in each of the supply chain sectors. Managers can use the findings of this study to purify the production processes and better manage projects, implement these items in design and management of supply chains, and prevent things like the bullwhip effect from happening by logistical management, coordination, and integration.

Findings of the research in the cluster "Intellectual capital and strategic management": Managers must note social capital as one of the most important factors in supply chain resilience. This factor, along with topics of learning and management of invisible capital, can create an appropriate relational capital for leadership and guidance of businesses in light of the strategic alliance. Given that intellectual capital includes human capital, structural capital, and relational capital, simultaneous consideration of all three factors can provide considerable help in creating strategic alliances and resilient networks. Interorganizational connections, including the connections between buyers and suppliers that can count as not only relational capital but also part of intellectual capital, can be exploited in expanding supply chains and strategically guiding them.

Findings of the research in the cluster "Critical success factors and alliances": Managers must simultaneously consider factors of trust, risk, and control and arrange better strategic cooperation. A key element in supply chain collaboration is creating balance between trust and control; using the findings of this research, managers can make decisions on the optimal level of trust in collaborations. Conversely, managers can also pay attention to communicating behaviors to expand new channels in marketing and inter-organizational cooperation. In the end, managers must consider factors of risk, trust, control, connections, contracts, marketing, communicating behaviors, long-term relationships, and justice to improve resilience. 


\section{Conclusions}

This article attempts to carry out a bibliometric analysis of literature in the field of strategic alliances and resilience in the supply chain. The paper also offers suggestions for future research by identifying the current gaps in literature and helps scholars find new research opportunities and offer some useful practical implications for both academics and managers. Literature gathered for analysis in this paper has come from the Web of Science (WoS) database; after a primary analysis, 518 studies were selected from 1995 to 2021. The rising year-to-year trend in article numbers, country participation in terms of number of articles and number of citations, journal profiles, studied fields, organizations, authors, keywords, and citations have been analyzed.

The results show a rapid growth in the rate of publications in recent years. Moreover, China, the United States (US), and the United Kingdom have the highest number of scientific productions and citations in this field. Furthermore, the highest number of articles has been published in the "International Journal of Production Economics", the "International Journal of Production Research", "Supply chain Management—an International Journal", "Sustainability", and "the Journal of Operations Management".

The top-5 resulted categories from data analysis are "Management", "Operations Research \& Management Science", "Business", "Industrial Engineering", and "Manufacturing Engineering". In addition, the most influential organization, with 20 publications, was The Hong Kong Polytechnic University. Furthermore, "Baofeng Huo" and "Zach G Zacharia" are the most productive researchers in this field.

The top- 5 keywords are performance, alliance, management, strategic alliance, and integration. Additionally, the highest number of local citations was from Petersen et al. (2005), published in the "Journal of Operations Management". Finally, Handfield, who was the most influential author with the highest number of total citations, is a main author of this article.

Author Contributions: Conceptualization, P.A. and M.P., methodology, P.A. and M.P.; software, M.P.; validation, M.A. and P.A.; formal analysis, M.P.; investigation, P.A. and M.A.; resources, M.P.; data curation, M.P.; writing—original draft preparation, M.P. and P.A.; writing—review and edit-ing, P.A.; visualization, M.A.; supervision, P.A. and M.A.; project administration, P.A. All authors have read and agreed to the published version of the manuscript.

Funding: This research received no external funding.

Institutional Review Board Statement: Not applicable.

Informed Consent Statement: Not applicable.

Data Availability Statement: Not applicable.

Conflicts of Interest: The authors declare no conflict of interest.

\section{References}

1. Rha, J.S. Trends of Research on Supply Chain Resilience: A Systematic Review Using Network Analysis. Sustainability 2020, 12, 4343. [CrossRef]

2. Ivanov, D. Revealing Interfaces of Supply Chain Resilience and Sustainability: A Simulation Study. Int. J. Prod. Res. 2018, 56, 3507-3523. [CrossRef]

3. Dolgui, A.; Ivanov, D.; Sokolov, B. Ripple Effect in the Supply Chain: An Analysis and Recent Literature. Int. J. Prod. Res. 2018, 56, 414-430. [CrossRef]

4. Hosseini, S.; Ivanov, D.; Dolgui, A. Review of Quantitative Methods for Supply Chain Resilience Analysis. Transp. Res. Part E Logist. Transp. Rev. 2019, 125, 285-307. [CrossRef]

5. Christopher, M.; Towill, D. An integrated model for the design of agile supply chains. Int. J. Phys. Distrib. Logist. Manag. 2001, 31, 235-246. [CrossRef]

6. Pfohl, H.-C.; Köhler, H.; Thomas, D. State of the art in supply chain risk management research: Empirical and conceptual findings and a roadmap for the implementation in practice. Logist. Res. 2010, 2, 33-44. [CrossRef]

7. Soni, U.; Jain, V.; Kumar, S. Measuring supply chain resilience using a deterministic modeling approach. Comput. Ind. Eng. 2014, 74, 11-25. [CrossRef] 
8. Ponomarov, S.Y.; Holcomb, M.C. Understanding the concept of supply chain resilience. Int. J. Logist. Manag. 2009, 20, 124-143. [CrossRef]

9. Carvalho, H.; Azevedo, S.G.; Cruz-Machado, V. Agile and resilient approaches to supply chain management: Influence on performance and competitiveness. Logist. Res. 2012, 4, 49-62. [CrossRef]

10. Gružauskas, V.; Vilkas, M. Managing capabilities for supply chain resilience through it integration. Econ. Bus. 2017, 31, 30-43. [CrossRef]

11. Kim, Y.; Chen, Y.S.; Linderman, K. Supply Network Disruption and Resilience: A Network Structural Perspective. J. Oper. Manag. 2015, 33, 43-59. [CrossRef]

12. Xu, S.; Zhang, X.; Feng, L.; Yang, W. Disruption risks in supply chain management: A literature review based on bibliometric analysis. Int. J. Prod. Res. 2020, 58, 3508-3526. [CrossRef]

13. Simchi-Levi, D.; Wang, D.; Wei, Y. Increasing Supply Chain Robustness Through Process Flexibility and Inventory. Prod. Oper. Manag. 2018, 27, 1476-1491. [CrossRef]

14. Yang, Y.; Pan, S.; Ballot, E. Mitigating Supply Chain Disruptions Through Interconnected Logistics Services in the Physical Internet. Int. J. Prod. Res. 2017, 55, 3970-3983. [CrossRef]

15. Shekarian, M.; Parast, M.M. An Integrative approach to supply chain disruption risk and resilience management: A literature review. Int. J. Logist. Res. Appl. 2020, 24, 427-455. [CrossRef]

16. Pettit, T.J.; Croxton, K.L.; Fiksel, J. Ensuring supply chain resilience: Development and implementation of an assessment tool. J. Bus. Logist. 2013, 34, 46-76. [CrossRef]

17. Wieland, A.; Wallenburg, C.M. The influence of relational competencies on supply chain resilience: A relational view. Int. J. Phys. Distrib. Logist. Manag. 2013, 43, 300-320. [CrossRef]

18. Murray, J.Y.; Kotabe, M. Performance implications of strategic fit between alliance attributes and alliance forms. J. Bus. Res. 2005, 58, 1525-1533. [CrossRef]

19. Mamedio, D.; Rocha, C.; Szczepanik, D.; Kato, H. Strategic alliances and dynamic capabilities: A systematic review. J. Strat. Manag. 2019, 12, 83-102. [CrossRef]

20. Wang, G.; Gunasekaran, A.; Ngai, E.W.; Papadopoulos, T. Big data analytics in logistics and supply chain management: Certain investigations for research and applications. Int. J. Prod. Econ. 2016, 176, 98-110. [CrossRef]

21. Zhao, D.; Strotmann, A. Analysis and visualization of citation networks. Synth. Lect. Inf. Concepts Retr. Serv. 2015, 7, 1-207. [CrossRef]

22. Xue, X.; Wang, L.; Yang, R. Exploring the science of resilience: Critical review and bibliometric analysis. Nat. Hazards 2018, 90, 477-510. [CrossRef]

23. Siddaway, A.P.; Wood, A.M.; Hedges, L.V. How to Do a Systematic Review: A Best Practice Guide for Conducting and Reporting Narrative Reviews, Meta-Analyses, and Meta-Syntheses. Annu. Rev. Psychol. 2018, 70, 747-770. [CrossRef]

24. Li, K.; Rollins, J.; Yan, E. Web of Science use in published research and review papers 1997-2017: A selective, dynamic, crossdomain, content-based analysis. Scientometrics 2018, 115, 1-20. [CrossRef]

25. Akhavan, P.; Elahi, B.; Mostafa, J. A new integrated knowledge model in supplier selection. Educ. Bus. Soc. Contemp. Middle East. Issues 2014, 7, 333-368. [CrossRef]

26. Ellram, L.M.; Tate, W.L.; Billington, C. Understanding and managing the services supply chain. J. Supply Chain Manag. 2004, 40, 17-32. [CrossRef]

27. Håkansson, H.; Persson, G. Supply chain management: The logic of supply chains and networks. Int. J. Logist. Manag. 2004, 15, 11-26. [CrossRef]

28. Caniato, F.F.A.; Rice, J. Building a secure and resilient supply chain. Supply Chain Manag. Rev. 2003, 7, $22-30$.

29. Christopher, M.; Peck, H. Building the Resilient Supply Chain. Int. J. Logist. Manag. 2004, 15, 1-13. [CrossRef]

30. Sheffi, Y.; Rice, J.B., Jr. A supply chain view of the resilient enterprise. MIT Sloan Manag. Rev. 2005, 47, 41.

31. Grötsch, V.M.; Blome, C.; Schleper, M.C. Antecedents of proactive supply chain risk management-a contingency theory perspective. Int. J. Prod. Res. 2013, 51, 2842-2867. [CrossRef]

32. Jafarnejad, A.; Momeni, M.; Hajiagha, S.H.R.; Khorshidi, M.F. A dynamic supply chain resilience model for medical equipment's industry. J. Model. Manag. 2019, 14, 816-840. [CrossRef]

33. Rajesh, R.; Ravi, V. Supplier selection in resilient supply chains: A grey relational analysis approach. J. Clean. Prod. 2015, 86, 343-359. [CrossRef]

34. Ambulkar, S.; Blackhurst, J.; Grawe, S. Firm's resilience to supply chain disruptions: Scale development and empirical examination. J. Oper. Manag. 2015, 33-34, 111-122. [CrossRef]

35. DAS, T.; Teng, B.-S. Trust, control, and risk in strategic alliances: An integrated framework. Organ. Stud. 2001, 22, 251-283. [CrossRef]

36. Sambasivan, M.; Yen, C.N. Strategic alliances in a manufacturing supply chain: Influence of organizational culture from the manufacturer's perspective. Int. J. Phys. Distrib. Logist. Manag. 2010, 40, 456-474. [CrossRef]

37. Hoffmann, W.H.; Schlosser, R. Success factors of strategic alliances in small and medium-sized enterprises-An empirical survey. Long Range Plan. 2001, 34, 357-381. [CrossRef]

38. Kale, P.; Singh, H. Building firm capabilities through learning: The role of the alliance learning process in alliance capability and firm-level alliance success. Strateg. Manag. J. 2007, 28, 981-1000. [CrossRef] 
39. Hitt, M.A.; Dacin, M.T.; Levitas, E.; Arregle, J.L.; Borza, A. Partner selection in emerging and developed market contexts: Resource-based and organizational learning perspectives. Acad. Manag. J. 2000, 43, 449-467.

40. Hoffmann, W.H. Strategies for managing a portfolio of alliances. Strat. Manag. J. 2007, 28, 827-856. [CrossRef]

41. Todeva, E.; Knoke, D. Strategic alliances and models of collaboration. Manag. Decis. 2005, 43, 123-148. [CrossRef]

42. Sarkar, M.; Aulakh, P.S.; Madhok, A. Process capabilities and value generation in alliance portfolios. Organ. Sci. 2009, 20, 583-600. [CrossRef]

43. Lehoux, N.; D'Amours, S.; Langevin, A. Inter-firm collaborations and supply chain coordination: Review of key element and case study. Prod. Plan. Control. 2014, 25, 858-872. [CrossRef]

44. Zacharia, Z.G.; Nix, N.W.; Lusch, R.F. An analysis of supply chain collaboration and their effect on performance outcomes. J. Bus. Logist. 2009, 30, 101-123. [CrossRef]

45. Kahn, K.B.; Maltz, E.N.; Mentzer, J.T. Demand collaboration effects on knowledge creation, relationships, and supply chain performance. J. Bus. Logist. 2006, 27, 191-221. [CrossRef]

46. Banomyong, R. Collaboration in supply chain management: A resilience perspective. Int. Transp. Forum Discuss. Pap. 2018, 22, $1-37$.

47. Liu, Z.; Yin, Y.; Liu, W.; Dunford, M. Visualizing the Intellectual Structure and Evolution of Innovation Systems Research: A Bibliometric Analysis. Scientometrics 2015, 103, 135-158. [CrossRef]

48. Ponomariov, B.; Boardman, C. What is co-authorship? Scientometrics 2016, 109, 1939-1963. [CrossRef]

49. Akhavan, P.; Ebrahim, N.A.; Fetrati, M.A.; Pezeshkan, A. Major trends in knowledge management research: A bibliometric study. Scientometrics 2016, 107, 1249-1264. [CrossRef]

50. Ding, Y.; Cronin, B. Popular and/or prestigious? Measures of scholarly esteem. Inf. Process. Manag. 2011, 47, 80-96. [CrossRef]

51. Petersen, K.J.; Handfield, R.B.; Ragatz, G.L. Supplier integration into new product development: Coordinating product, process and supply chain design. J. Oper. Manag. 2005, 23, 371-388. [CrossRef]

52. Krause, D.R.; Handfield, R.B.; Tyler, B.B. The relationships between supplier development, commitment, social capital accumulation and performance improvement. J. Oper. Manag. 2006, 25, 528-545. [CrossRef]

53. Paulraj, A.; Lado, A.A.; Chen, I.J. Inter-organizational communication as a relational competency: Antecedents and performance outcomes in collaborative buyer-supplier relationships. J. Oper. Manag. 2008, 26, 45-64. [CrossRef]

54. Nyaga, G.N.; Whipple, J.M.; Lynch, D.F. Examining supply chain relationships: Do buyer and supplier perspectives on collaborative relationships differ? J. Oper. Manag. 2010, 28, 101-114. [CrossRef]

55. Villena, V.H.; Revilla, E.; Choi, T.Y. The dark side of buyer-supplier relationships: A social capital perspective. J. Oper. Manag. 2011, 29, 561-576. [CrossRef]

56. Monczka, R.M.; Petersen, K.J.; Handfield, R.B.; Ragatz, G.L. Success factors in strategic supplier alliances: The buying company perspective. Decis. Sci. 1998, 29, 553-577. [CrossRef]

57. Li, S.; Lin, B. Accessing information sharing and information quality in supply chain management. Decis. Support Syst. 2006, 42, 1641-1656. [CrossRef]

58. Gunasekaran, A.; Ngai, E.W.T. Knowledge management in 21st century manufacturing. Int. J. Prod. Res. 2007, 45, 2391-2418. [CrossRef]

59. Ireland, R.D.; Webb, J.W. A multi-theoretic perspective on trust and power in strategic supply chains. J. Oper. Manag. 2007, 25, 482-497. [CrossRef]

60. Power, D. Supply chain management integration and implementation: A literature review. Supply Chain Manag. Int. J. 2005, 10, 252-263. [CrossRef]

61. Ding, Y.; Yan, E.; Frazho, A.; Caverlee, J. PageRank for Ranking Authors in co-Citation Networks. J. Am. Soc. Inf. Sci. Technol. 2009, 60, 2229-2243. [CrossRef]

62. Fahimnia, B.; Sarkis, J.; Davarzani, H. Green Supply Chain Management: A Review and Bibliometric Analysis. Int. J. Prod. Econ. 2015, 162, 101-114. [CrossRef]

63. Brin, S.; Page, L. The Anatomy of a Large-Scale Hypertextual web Search Engine. Comput. Netw. ISDN Syst. 1998, 30, 107-117. [CrossRef]

64. Lawson, B.; Tyler, B.B.; Cousins, P.D. Antecedents and consequences of social capital on buyer performance improvement. J. Oper. Manag. 2008, 26, 446-460. [CrossRef]

65. Cheng, J.; Yeh, C.-H.; Tu, C. Trust and knowledge sharing in green supply chains. Supply Chain Manag. Int. J. 2008, 13, 283-295. [CrossRef]

66. Koufteros, X.A.; Cheng, T.E.; Lai, K.H. "Black-box" and "gray-box" supplier integration in product development: Antecedents, consequences and the moderating role of firm size. J. Oper. Manag. 2007, 25, 847-870. [CrossRef]

67. Boddy, D.; Macbeth, D.; Wagner, B. Implementing collaboration between organizations: An empirical study of supply chain partnering. J. Manag. Stud. 2000, 37, 1003-1018. [CrossRef]

68. Leydesdorff, L.; Barnett, G. Bibliometrics/citation networks. arXiv 2012, arXiv:1502.06378.

69. Yu, D.; Xu, Z.; Wang, W. Bibliometric Analysis of Fuzzy Theory Research in China: A 30-Year Perspective. Knowl.-Based Syst. 2018, 141, 188-199. [CrossRef]

70. Charvet, F.F.; Cooper, M.C.; Gardner, J.T. The Intellectual Structure of Supply Chain Management: A Bibliometric Approach. J. Bus. Logist. 2008, 29, 47-73. [CrossRef] 
71. Grant, R.M. Toward a knowledge-based theory of the firm. Strat. Manag. J. 1996, 17, 109-122. [CrossRef]

72. Vachon, S.; Klassen, R.D. Environmental management and manufacturing performance: The role of collaboration in the supply chain. Int. J. Prod. Econ. 2008, 111, 299-315. [CrossRef]

73. Ragatz, G.L.; Handfield, R.; Petersen, K.J. Benefits associated with supplier integration into new product development under conditions of technology uncertainty. J. Bus. Res. 2002, 55, 389-400. [CrossRef]

74. Adler, P.S. Corporate scandals: It's time for reflection in business schools. Acad. Manag. Perspect. 2002, 16, 148-149. [CrossRef]

75. Anderson, J.C.; Narus, J.A. A model of distributor firm and manufacturer firm working partnerships. J. Mark. 1990, 54, 42-58. [CrossRef]

76. Kogut, B.; Zander, U. Knowledge of the firm, combinative capabilities, and the replication of technology. Organ. Sci. 1992, 3, 383-397. [CrossRef]

77. Fornell, C.; Larcker, D.F. Evaluating structural equation models with unobservable variables and measurement error. J. Mark. Res. 1981, 18, 39-50. [CrossRef]

78. Carr, A.S.; Pearson, J.N. Strategically managed buyer-supplier relationships and performance outcomes. J. Oper. Manag. 1999, 17, 497-519. [CrossRef]

79. Autry, C.W.; Zacharia, Z.G.; Lamb, C.W. A logistics strategy taxonomy. J. Bus. Logist. 2008, 29, 27-51. [CrossRef]

80. Tranfield, D.; Denyer, D.; Smart, P. Towards a methodology for developing evidence-informed management knowledge by means of systematic review. Br. J. Manag. 2003, 14, 207-222. [CrossRef]

81. Jap, S.D. Pie-expansion efforts: Collaboration processes in buyer-supplier relationships. J. Mark. Res. 1999, 36, 461-475.

82. Dyer, J.H. Specialized supplier networks as a source of competitive advantage: Evidence from the auto industry. Strateg. Manag. J. 1996, 17, 271-291. [CrossRef]

83. Benton, W.C.; Maloni, M. The influence of power driven buyer/seller relationships on supply chain satisfaction. J. Oper. Manag. 2005, 23, 1-22. [CrossRef]

84. Lavie, D. Alliance portfolios and firm performance: A study of value creation and appropriation in the US software industry. Strateg. Manag. J. 2007, 28, 1187-1212. [CrossRef]

85. Christopher, M. (Ed.) Logistics: The Strategic Issues; Chapman \& Hall: London, UK, 1992.

86. Burt, R.S.; Celotto, N. The network structure of management roles in a large matrix firm. Eval.Program Plan. 1992, 15, 303-326. [CrossRef]

87. Ganesan, S. Determinants of long-term orientation in buyer-seller relationships. J. Mark. 1994, 58, 1-19. [CrossRef]

88. Dyer, J.H.; Singh, H. The relational view: Cooperative strategy and sources of interorganizational competitive advantage. Acad. Manag. Rev. 1998, 23, 660-679. [CrossRef]

89. Frohlich, M.T.; Westbrook, R. Arcs of integration: An international study of supply chain strategies. J. Oper. Manag. 2001, 19, 185-200. [CrossRef]

90. Carey, S.; Lawson, B.; Krause, D.R. Social capital configuration, legal bonds and performance in buyer-supplier relationships. J. Oper. Manag. 2011, 29, 277-288. [CrossRef]

91. Kumar, N.; Scheer, L.K.; Steenkamp, J.B.E. The effects of supplier fairness on vulnerable resellers. J. Mark. Res. 1995, 32, 54-65. [CrossRef]

92. Hamel, G. Collaborate with your competitors and win. Harv. Bus. Rev. 1989, 67, 133-139.

93. Podsakoff, P.M.; MacKenzie, S.B.; Lee, J.Y.; Podsakoff, N.P. Common method biases in behavioral research: A critical review of the literature and recommended remedies. J. Appl. Psychol. 2003, 88, 879. [CrossRef]

94. Lee, H.L.; Padmanabhan, V.; Whang, S. The bullwhip effect in supply chains. Sloan Manag. Rev. 1997, 38, 93-102. [CrossRef]

95. Coleman, J.S. Social capital in the creation of human capital. Am. J. Sociol. 1988, 94, S95-S120. [CrossRef]

96. Lusch, R.F.; Brown, J.R. Interdependency, contracting, and relational behavior in marketing channels. J. Mark. 1996, 60, 19-38. [CrossRef]

97. Lavie, D. The competitive advantage of interconnected firms: An extension of the resource-based view. Acad. Manag. Rev. 2006, 31, 638-658. [CrossRef]

98. Sarkar, M.; Echambadi, R.; Cavusgil, S.T.; Aulakh, P.S. The influence of complementarity, compatibility, and relationship capital on alliance performance. J. Acad. Mark. Sci. 2001, 29, 358-373. [CrossRef]

99. Mentzer, J.T.; DeWitt, W.; Keebler, J.S.; Min, S.; Nix, N.W.; Smith, C.D.; Zacharia, Z.G. Defining supply chain management. J. Bus. Logist. 2001, 22, 1-25. [CrossRef]

100. Cousins, P.D.; Menguc, B. The implications of socialization and integration in supply chain management. J. Oper. Manag. 2006, 24, 604-620. [CrossRef]

101. Mayer, R.C.; Davis, J.H.; Schoorman, F.D. An integrative model of organizational trust. Acad. Manag. Rev. 1995, $20,709-734$. [CrossRef]

102. Teece, D.J. Profiting from technological innovation: Implications for integration, collaboration, licensing and public policy. Res. Policy 1986, 15, 285-305. [CrossRef]

103. Wittmann, C.M.; Hunt, S.D.; Arnett, D.B. Explaining alliance success: Competences, resources, relational factors, and resourceadvantage theory. Ind. Mark. Manag. 2009, 38, 743-756. [CrossRef]

104. Womack, J.P.; Jones, D.T.; Roos, D. How lean production can change the world. The New York Times, 23 September 1990; 20-38. 
105. Inkpen, A.C. Strategic Alliances. In The Blackwell Handbook of Strategic Management; Wiley Online Library: Hoboken, NJ, USA, 2005; pp. 403-427.

106. Miles, M.B.; Huberman, A.M. Qualitative Data Analysis: An Expanded Sourcebook; Sage: Thousand Oaks, CA, USA, 1994.

107. Eisenhardt, K.M.; Schoonhoven, C.B. Resource-based view of strategic alliance formation: Strategic and social effects in entrepreneurial firms. Organ. Sci. 1996, 7, 136-150. [CrossRef]

108. Armstrong, J.S. Social irresponsibility in management. J. Bus. Res. 1977, 5, 185-213. [CrossRef]

109. Kotabe, M.; Martin, X.; Domoto, H. Gaining from vertical partnerships: Knowledge transfer, relationship duration, and supplier performance improvement in the US and Japanese automotive industries. Strateg. Manag. J. 2003, 24, 293-316. [CrossRef]

110. Kale, P.; Singh, H.; Perlmutter, H. Learning and protection of proprietary assets in strategic alliances: Building relational capital. Strateg. Manag. J. 2000, 21, 217-237. [CrossRef]

111. Morgan, R.M.; Hunt, S.D. The commitment-trust theory of relationship marketing. J. Mark. 1994, 58, 20-38. [CrossRef]

112. Gulati, R.; Nohria, N.; Zaheer, A. Strategic networks. Strateg. Manag. J. 2000, 21, 203-215. [CrossRef]

113. Nunnally, J.C.; Bernstein, I.H. Psychometric Theory; McGraw-Hill: New York, NY, USA, 1994.

114. Clark, K.B. Project scope and project performance: The effect of parts strategy and supplier involvement on product development. Manag. Sci. 1989, 35, 1247-1263. [CrossRef]

115. Zaheer, A.; McEvily, B.; Perrone, V. Does trust matter? Exploring the effects of interorganizational and interpersonal trust on performance. Organ. Sci. 1998, 9, 141-159. [CrossRef]

116. Mandal, S. An empirical investigation into supply chain resilience. IUP J. Supply Chain. Manag. 2012, 9, 46.

117. Christoffersen, J. A review of antecedents of international strategic alliance performance: Synthesized evidence and new directions for core constructs. Int. J. Manag. Rev. 2013, 15, 66-85. [CrossRef]

118. Spieske, A.; Birkel, H. Improving supply chain resilience through industry 4.0: A systematic literature review under the impressions of the COVID-19 pandemic. Comput. Ind. Eng. 2021, 158, 107452. [CrossRef]

119. Mubarik, M.S.; Bontis, N.; Mubarik, M.; Mahmood, T. Intellectual capital and supply chain resilience. J. Intellect. Cap. 2021. ahead of print. [CrossRef]

120. Bayramova, A.; Edwards, D.; Roberts, C. The role of blockchain technology in augmenting supply chain resilience to cybercrime. Buildings 2021, 11, 283. [CrossRef]

121. Fayezi, S.; Ghaderi, H. What are the mechanisms through which inter-organizational relationships contribute to supply chain resilience? Asia Pac. J. Mark. Logist. 2021. ahead of print. [CrossRef]

122. Lim, H.W.; Zhang, F.; Fang, D.; Peña-Mora, F.; Liao, P.C. Corporate social responsibility on disaster resilience issues by international contractors. J. Manag. Eng. 2021, 37, 04020089. [CrossRef]

123. Jain, V.; Kumar, S.; Soni, S.; Chandra, C. Supply chain resilience: Model development and empirical analysis. Int. J. Prod. Res. 2017, 55, 6779-6800. [CrossRef]

124. Mishra, D.; Gunasekaran, A.; Papadopoulos, T.; Childe, S.J. Big Data and Supply Chain Management: A Review and Bibliometric Analysis. Ann. Oper. Res. 2018, 270, 313-336. [CrossRef]

125. Min, H. Blockchain Technology for Enhancing Supply Chain Resilience. Bus. Horiz. 2019, 62, 35-45. [CrossRef] 